\title{
Interactive comment on "Impacts of land use/cover change and reforestation on summer rainfall for the Yangtze River Basin” by Wei Li et al.
}

Wei Li et al.

wei.lee@whu.edu.cn

Received and published: 19 January 2021

The comment was uploaded in the form of a supplement:

https://hess.copernicus.org/preprints/hess-2020-441/hess-2020-441-AC3-

supplement.pdf

Interactive comment on Hydrol. Earth Syst. Sci. Discuss., https://doi.org/10.5194/hess-2020441, 2020. 